İşletme Ekonomi ve Yönetim Araştırmaları Dergisi

(The Journal of Business, Economic and Management Research)

Y1l 2021 / Say1: 1 / 193 - 218

Araşturma Makalesi

Gönderilme Tarihi: 30 Kasım 2020; Revize Edilmiş Hali: 18 Ocak 2021; Kabul Tarihi: 20 Şubat 2021

\title{
MARKET LIBERALIZATION IMPACT ON OIL RETAIL PRICES IN NORTH MACEDONIA AND THE EX YU REGION
}

\section{EDVIN MUSHE ${ }^{1}$}

\section{ABSTRACT}

Market liberalization is often regarded as a process of freeing the market from all types of monopolies, which should eventually increase the competition and provide better offer followed by lowers prices. In terms of oil economics, regulated oil retail prices are often regarded as contra productive for sustainable economic growth. Market liberalization contributes for countries not to depend on a single company in the import and sales of oil products and thus guarantees energy stability. Liberalization and oil retail prices are often interrelated and the effect of its interaction is usually the one affecting the prospects of the entire economy.

This paper emphasizes the importance of market liberalization and its influence on oil retail prices. This paper is explicitly focused on the leading oil companies in North Macedonia and the Ex Yu region. The aim of this paper is to present the market liberalization process in the oil industry by analyzing the effect of market liberalization on oil retail prices. The research is concentrated on six leading oil companies, with particular focus on the oil retail prices. The research outcome revealed that full market liberalization is not always beneficial and might have different effect on country's business economy and energy infrastructure.

Key words: market liberalization, oil industry, oil retail prices

JEL Classification: Q02; Q43; Q48

\section{KUZEY MAKEDONYA VE ESKI YUGOSLAVYA BÖLGESINDE, PETROL PİYASASININ LIBBERALLEŞMESININ PETROL PERAKENDE FIYATLARI ÜZERİNDEKİ ETKİSI}

Öz

Piyasa liberalizasyonu genel olarak piyasayı her tür tekel piyasadan kurtarma süreci olarak kabul edilerek, rekabeti arttırmalı ve daha iyi teklif sunarak fiyatları düşürmelidir. Petrol ekonomisi açısından, düzenlenmiş petrol perakende fiyatları genellikle sürdürülebilir ekonomik büyüme için ters üretken olarak kabul edilmektedir. Piyasanın liberalleşmesi, ülkelerin petrol ürünlerinin ithalatında ve satışında tek bir şirkete bağlı kalmamasına katkıda bulunarak enerji istikrarını garanti altına alır. Liberalleşme ve petrol perakende fiyatları genellikle ters orantılıdır, ve bu orantı genellikle tüm ekonominin beklentilerini etkiler. $\mathrm{Bu}$ makale, piyasa liberalizasyonunun önemini ve bunun perakende petrol fiyatları üzerindeki etkisini vurgulamaktadır.

Bu makale, piyasa liberalizasyonunun önemini ve bunun perakende petrol fiyatları üzerindeki etkisini vurgulamaktadır. $\mathrm{Bu}$ makale açıkça Kuzey Makedonya ve Eski Yugoslavya bölgesindeki önde gelen petrol şirketlerine odaklanmıştır. Bu makalenin amacı, petrol piyasası liberalizasyonunun perakende petrol fiyatları üzerindeki etkisini analiz ederek petrol endüstrisindeki piyasa liberalizasyon sürecini sunmaktır. Araştırma, özellikle petrol perakende fiyatlarına odaklanarak önde gelen altı petrol şirketi üzerinde yoğunlaşmıştır. Araştırma sonucu, tam piyasa liberalizasyonunun her zaman yararlı olmadığını ve ülkenin iş ekonomisi ve enerji alyapısı üzerinde farklı etkileri olabileceğini ortaya koydu.

Anahtar kelimeler: piyasa liberalizasyonu, petrol endüstrisi, petrol perakende fiyatları

${ }^{1}$ edvin_mushe@yahoo.com, 0000-0003-2124-4576 
JEL Kodları: Q02; Q43; Q48

\section{Introduction}

In the oil industry, the concept of market liberalization is rather complex issue especially for development economies. From a practical perspective, market liberalization implies the deliberate creation of systematic and economic policy measures, starting from antitrust and anti-dumping laws, to various measures of monetary and fiscal policy. Transformations of market structures followed by strict government regulations, often results in decreased competition and higher market prices. The basic of every market economy is the existence of competition and its progress is relatively influenced by the constraints imposed by legal entities. This stance, however, has changed significantly in the past decade due to the rising notion of open markets. The new liberalized structure has rapidly evolved within commodity markets and reshaped the competitive landscape of global oil companies. Oil companies compete on price and each economic variation of crude oil prices on the global market might influence its profit margin. Market liberalization can contribute toward eliminating government obstacles and stimulate broader competition and different oil retail prices.

This study discusses how liberalization impacts oil retail prices of North Macedonia by comparing the effect of market liberalization on oil retail prices of Ex Yu countries. Given the importance of market liberalization for oil retail prices, in this paper the focus is on showing the relevance of this correlation. The reason why North Macedonia was selected as a sample country is because the liberalization of oil retail prices in this country has not been implemented yet. Hence the comparison with the Ex Yu countries is made primarily to show how full liberalization affects oil retail prices. This is done to serve as an indicator for North Macedonia of the potential benefits or detriments of liberalized oil markets and its different impact on the future formation of oil retail prices. This study also contributed to the existing literature of market liberalization. Both theoretical and empirical findings had generated more profound understanding of the relationship between market liberalization and oil retail prices by presenting a different scientific perspective regarding the potential risks and advantages of a liberalized oil retail prices. The practical implication of this study will benefit oil companies in North Macedonia to better comprehend the impact of oil price liberalization and its economic benefit for consumers and the energy market.

\section{Research overview}

The structure of this study was divided into four main sections. Each section followed a logical flow of discussion and was contextually related with the main research topic. The first section elaborated on the general framework of oil price regulations in the oil industry and draws a clear distinction among 
regulated and liberalized markets. The second section focused on market liberalization and oil price formation in North Macedonia and the Ex Yu region, by presenting different mathematical formulas of few selected countries and the means how each countries computes its oil retail prices. The third section discussed the structure of oil retail prices in North Macedonia and the Ex Yu region and elaborated on the importance of different economic parameters that influence the overall net price of oil derivatives. The fourth and last section concentrated on the impact of market liberalization on oil retail prices in North Macedonia and the Ex Yu region, before and after market liberalization.

\section{MARKET LIBERALIZATION AND OIL PRICE REGULATIONS IN THE OIL INDUSTRY}

For the sake of the large net income, the global oil industry has long been defined as a closed entity rather than as a pragmatic contributor. According to Goldthau and Witte (2008), this perspective, which emerged far back from the Standard Oil era, is completely opposite from the market economy principles and the existence of competition in general. In the oil industry, the key argument suggests that liberalization evidently affects different business sectors and intensifies rivalry between companies on the market. Starting from the 1990's, market liberalization has often been regarded as a relevant tool for increasing competitiveness and boosting domestic economy. As stated by Baumol et al., (1982), economics theory projects that increased competition will stimulate lower prices and eventually higher outputs. Altogether, this means a greater benefit for consumers by providing more quality offer on the market. On the contrary, monopolies might restrict output and hence increase prices, imposing additional burden to consumers.

In order to mitigate oil price shocks and to adjust on the novel legal frameworks, governments have come up with a three generic price controls defined as oil price mechanism displayed in Table 1.

Table 1: Oil price regulations framework around the world

\begin{tabular}{|l|l|l|}
\hline Price Mechanism & Advantages & Issues \\
\hline Price celling & $\begin{array}{l}\text { Protects customers from price } \\
\text { fluctuations and high market } \\
\text { prices. }\end{array}$ & $\begin{array}{l}\text { If price celling price are too } \\
\text { high, there is a little incentive to } \\
\text { improve efficiency. If they are too } \\
\text { low, fuel business may cease to } \\
\text { be financially viable. }\end{array}$ \\
\hline Free & $\begin{array}{l}\text { Oil retailers set their own prices } \\
\text { freely without any specific } \\
\text { government restriction. }\end{array}$ & $\begin{array}{l}\text { Oil retail prices may differ } \\
\text { throughout the country, } \\
\text { depending on the oil station } \\
\text { location. }\end{array}$ \\
\hline Fixed & $\begin{array}{l}\text { Most extreme form of price } \\
\text { control regulated by the }\end{array}$ & $\begin{array}{l}\text { Oil retail prices are fixed and all } \\
\text { retailers are obliged to sell under }\end{array}$ \\
\hline
\end{tabular}




\begin{tabular}{|l|lr|l|}
\hline & $\begin{array}{l}\text { government or specific } \\
\text { institution. }\end{array}$ & same price. \\
\hline
\end{tabular}

Source: Kojima (2013)

As explained in Table 1, each price mechanism is unique in its own terms, and its applicable nature varies throughout each country in the world. Government's economic structure and policy shape the liberalized market to the extent suitable for its long term energy strategy. This approach has gradually changed the interventionist role of economies which tend to protect its resources by imposing legal obstructions in order to diminish competition. The correlation between liberalization and oil price regulations is usually misinterpreted in the academic community, mainly due to its complex legal content and decreased focus on rivalry (Benedict et al., 2003).

Whether oil price liberalization is productive depends solely of the type of pricing strategies and its impact on consumers' future demand. As a daunting process, hence, market liberalization may or may not always have positive impact on oil retail prices perceived from stakeholder perspective (Husain et al., 2015). In that context, it is of utmost importance for each country to carefully measure the effects of liberalization on oil retail prices. As stressed by Capece et al., (2007), once the market is fully liberalized, it is necessary to apply evaluation mechanisms thus enabling countries to easily prevent unwanted price oscillation.

Within the economic practical and theoretical literature, there have always been scientific confrontations regarding which option is more lucrative in terms of market freedom. Whether oil retail prices should remain regulated or liberalized depends on companies' market structure and legal politics.

Regulated oil prices are in essence a productive source of governments' income. The strategic context of this issue is rather misunderstood when it comes to certain regulations which negatively impacts oil companies' profit. Constant amplification of the economic and legal measures causes dissatisfaction of oil companies and financial turbulence in its ongoing projections. Nevertheless, legal obstructions often diminish the competitive character of oil companies thus eliminating its effort to compete on price. In regulated oil markets, companies have fewer available methods on which they can strategically compete (Mitchell et al., 2012). In the context of price celling mechanism, one of the easiest ways to generate higher net income is to intentionally decrease the percent of the profit margin incorporated in the mathematical formula. At the expense of higher sales, companies can easily justify its lower profit margin and cover its financial gaps with bigger revenues. However, due to the highly concentrated and saturated structure of these markets, oil retail companies opt to follow an identical price and rarely choose to risk their steady returns (Carollo, 2011).

In developing economies, the government is the one that takes initiative to periodically reduce the excise duties on oil products in order to stimulate economic growth and consumption itself. This approach 
is still present in the practice and has generated sufficient results by improving the development prospects of countries' business economics. Therefore it is not unusual, neither in transition nor in developed market economies, that the state, taking care of all segments of the resident market, actually directs the liberalization process by gradually harmonizing the interests of different market players (Joubert et al., 2018). On this way, the state indirectly favors the interest of certain market player and might change its preference overtime by preferring other market player, thus maintaining its equilibrium role to secure stability within the market as a whole. In order to prevent further government turmoil, it is essential to proclaim equality not only in declarative terms, but also in practical context.

As observed by Price (2005), the more the government increases its role of strengthening its legal capacities of market regulations, the more it diminishes the competitive character of its oil industry. Interestingly, regulated oil markets are characteristic for less developed countries which are not prone to change, or for countries which lack capacities of market expansion. When a market has a limited absorption power, with small variations in demand, it becomes extremely difficult to adapt to changes if the market is unregulated. Thus government's role is to keep a steady price and protect its energy future by constantly changing its regulation norms with single price methodology in place. In a long term, this approach will not sustain, given the current market conditions, and will only degrade companies' strategic outlook. The inability to adapt to a newer economic framework translates into hiding behind a 'productive' system of non-pragmatic decisions. Theoretically, the economic condition of a certain state is a direct consequence of governments' politics and measures. Whether this relation will change overtime depends only on companies' proactive approach towards implementing changes, and last but not least, on market structure and readiness (Garcia, 2010).

Liberalized oil markets, on the other hand, are completely free from any restrictions and government regulations. As stated by Pollitt (2012), the rapid modernization of Western and European oil markets had somehow altered the outdated conceptual philosophy of government leadership. To prosper and grow, companies need to compete. To compete fairly, they need an unregulated free market and attractive business environment on which they can thrive. An open market will bring greater responsibility to all market participants and they will have to ensure security of supply, fuel quality, and affordable prices. The biggest concern of each country's liberalization strategy is the fear of uncontrolled prices hikes, which necessarily appear under different economic scenarios. This issue raises another contradictory question: Does liberalization indeed decreases or increases oil retail prices? According to the analysis and experience of the neighboring countries, liberalization, to a certain extent, increases oil prices, especially if there is only one major participant with a dominant market share (Association of Oil Companies of Serbia, 2011). On the contrary, Pintado and Cavero (2008) argued that liberalization of oil markets by increasing competition in traditionally monopolistic environment generates benefits for 
consumers and better quality of products. Consumers have more choice, which in principle creates better quality of service and lower price, which depends solely of the competitive relations among oil companies on the market (Debab and Radhi, 2011).

According to Musselli and Zarrilli (2005), when the market is monopolized, once liberalized, there is a great danger of sudden price hikes on which monopolized companies are entitled to. With this scenario in place, Danwitz (2006) argued that countries are usually forced to postpone the liberalization process until other market participants appear hence boosting the competitive character of the industry itself. Bigger competition means rationalizing of operations and lowering market costs of rival entities (Porter, 1985). Moreover, Bacon and Kojima (2010) emphasized that when the price of crude oil on the global market declines, companies are prone not to instantly lower the retail prices of oil. In the opposite situation, they are always ready to raise the prices immediately. Statistically, this correlation is known as the 'Feather and Rocket' effect, indicating the asymmetric effect of global oil prices on oil retail prices. In practical terms, the concept of liberalized markets is usually unsustainable when it comes to oil industry. Thus Wieringa and Verhoef (2007) elaborated that the main reason lies within the inversely proportional relation among liberalization benefits and customer expectations and switching habits. Fasoula and Schweikert (2018) pointed out that when oil retail prices are regulated, there is no room for large price maneuvers, since oil companies are obliged to follow a certain methodology and adapt its prices accordingly. When oil prices are liberalized, companies modify their prices to increase profits, neglecting consumers' sensitivity and quality improvement. Therefore, the start of any liberalization is often guided by government officials, primarily to mitigate any potential setbacks by transferring price risks both on suppliers and consumers. In a situation when liberalized oil prices have not given the expected results, the government, by all means, has the right, retroactively, to impose previous regulation measures and determine the highest retail prices of a certain oil product. Thus governments protect consumers by preventing major shifts in demand (Acheampong and Ackah, 2015).

According to Szulecki (2016), EU countries politics is rather embedded in the European Climate and Energy Framework. This means that each new country member has the obligation to profoundly change its ongoing energy politics in order to integrate it closely to the EU practice legislation. Indirectly, this legal transformation opens up a completely new chapter with primary focus on reforms and harmonization of economic and energy politics. In other words, deregulation and de-monopolization of oil markets and restructuring towards full market liberalization. As complex and lengthy this process might seem, its dynamics largely depends on the countries dedication and its desire to transform the energy future and secure long term market stability. 


\section{THE OIL PRICE FORMATION MODELS IN NORTH MACEDONIA AND THE EX YU REGION}

Due to its poor energetic structure and complex legal system, North Macedonia has partially liberalized its market for oil derivatives, only in terms of oil imports and exports, whereas the oil retail price still remains controlled. The liberalization is implemented only in declarative terms with a serious lack of practical integration. However, the process of full liberalization of the oil market is completed in few countries of the region, with exceptions to countries that are exceptionally slow toward adapting to the new market regulations. In the context of encouraging more competition on the market, as well as accelerating the dynamics of the 'free market prices', the debate about the liberalization of oil retail prices is still active in the region. The basic structure of which current oil prices are set in the region is relatively similar to the one used on the global oil market, where oil retail prices are formed on the basis of actual supply and demand on the market. Through the harmonization of energy legislation with the EU directives, regional countries are working intensively in the direction of full liberalization of the oil market, hence providing space for free capital investment and equal competitiveness.

Table 2: Oil retail price mechanism in North Macedonia and the Ex Yu region

\begin{tabular}{|l|c|c|}
\hline Company & Mechanism & Market structure \\
\hline $\begin{array}{l}\text { 1.Makpetrol AD } \\
\text { (North Macedonia) }\end{array}$ & Price celling & Regulated \\
\hline 2.NIS AD (Serbia) & Free & Liberalized \\
\hline $\begin{array}{lr}\text { 3.INA AD (Croatia) } \\
\text { 4.Energopetrol AD } \\
\text { (Bosnia } \\
\text { Herzegovina) }\end{array}$ & Free & Liberalized \\
\hline $\begin{array}{l}\text { 5.Jugopetrol AD } \\
\text { (Montenegro) }\end{array}$ & Price celling & Regulated \\
\hline $\begin{array}{l}\text { 6.Petrol AD } \\
\text { (Slovenia) }\end{array}$ & Price celling & Regulated \\
\hline
\end{tabular}

Source: Author's research

As shown in Table 2, oil retail prices in North Macedonia and the Ex Yu region are a subject of different price mechanism. Oil retail prices in North Macedonia are under the guidance of the Energy regulatory commission (ERC), which is responsible for setting and altering the retail price of oil products, according to the principle of 'price celling'. On this way the state protects its consumers by preventing any kind of potential monopoly association. The same principle applies in Slovenia, Montenegro and Bosnia and Hercegovina, where oil retail prices are under strict Government regulation. The current 
policy still initiates deep criticism from the global energy community, primarily because of the noncompetitive oil retail prices and the expressed heterogeneous structure of these oil markets. Croatia and Serbia are the only countries in the Ex Yu region that have free oil retail prices which are market determined. The oil retail prices in these two countries are different for each oil company and they are frequently determined according to the genuine location and quality of oil products.

According to the contract signed between North Macedonia and Greece in 1999 regarding the purchase of the OKTA Refinery and in compliance with the Annex D of the agreement, the Energy regulatory commission of North Macedonia was obliged to adjust its price methodology in accordance with specific principles highlighted in the contract. The contract duration was 20 years. Since the contract ceased in May, 2019, oil retail prices in Macedonia remained to be determined by the Energy regulatory commission (ERC, 2019). Its main obligation is to establish maximum retail prices (price celling) for oil products and maintain oil price stability. The price changes in accordance with the global oil prices (Brent) and the movement of referent prices of certain oil derivatives published in the stock exchange report Platt's Crude Oil Spot Price and the dynamics of the exchange rates of US dollar and Macedonian denar in the past 14 days period. Additional components that are part of the actual methodology of oil retail prices in North Macedonia are shown in Table 2.1.

Table 2.1: Oil retail price methodology framework of North Macedonia

\begin{tabular}{|rl|}
\hline 1. & Refinery price of oil derivatives \\
\hline 2. & Trade margin \\
\hline 3. & Transportation costs \\
\hline 4. & Excise on oil products \\
\hline 5. & Value added tax \\
\hline 6. & Environmental activities \\
\hline 7. & Compulsory oil derivatives \\
\hline
\end{tabular}

Source: ERC (2019)

Unlike North Macedonia, which neither produce nor refines oil, both Serbia and Croatia possess their own refinery capacities. Companies such as NIS AD (Serbia) and INA AD (Croatia) are vertically integrated by its structure. They have the entire control of its operations within the value chain, from upstream to downstream activities thus implementing a more advanced pricing approach. Its retail pricing is similar with the methodology used in the global oil industry, with few additional parameters incorporated in the equation. Both formulas presented below appear similar at first glance. However, each has its own economic relevance in regards to the mathematical concept used in determining oil prices. In 
Serbia, oil retail prices are calculated based on the formula in which main variables are the price of crude oil and the dollar exchange rate. For each change of the price of crude oil greater than $2.5 \%$ converted into dinars and on the basis of the current dollar exchange rate, a new retail price of oil is calculated. Additionally, oil retail prices in Serbia also depend on the excise duties and value added tax (VAT). When refinery costs are up, they can instantly lift the retail prices of oil thus causing major implications for retail sellers and substantial impact on consumer demand.

In Serbia, oil retail prices are calculated according to the following formula (Udovicki and Djokovic, 2005, p.5):

$$
P=\mathrm{C}_{N A F T E+} \mathrm{C}_{T r}+\mathrm{C}_{R}+\mathrm{C}_{D+} T
$$

Where:

$P$ - Retail price of oil derivatives

CNAFTE - Price of crude oil

$\mathrm{CTr}$ - Intermediary and transportation costs

$\mathrm{CR}$ - Refining costs and profit

CD - Distribution costs

$\mathrm{T}-$ Tax (Excise and VAT)

Whereas, according to the Croatian Oil Model, the retail price of oil is computed as follows (Bajo and Klemencic, 2012, p. 119):

$$
C_{\text {max }}=\left(\frac{\sum_{i=1}^{n} \text { CIFMed }_{i} T_{i}}{n}+H\right) x \frac{\rho}{1000}+B+P
$$

Where:

Cmax - Maximum price in Kn/l

CIF Med - Average daily stock price of oil products in USD/t (Platt's European Market Scan)

$\boldsymbol{T}$ - Average daily exchange rate in HRK/USD

$\boldsymbol{i}$-Daily information: $i=1,2,3, \ldots, n$

$\boldsymbol{n}$ - Number of average published stock exchange prices of oil products (CIF Max) in the accounting period

$$
\boldsymbol{p} \text {-Density of petroleum products (for motor oil } p=0,755 \mathrm{~kg} / \mathrm{l} \text {; for diesel and gas oils } \quad p=
$$
$0.845 \mathrm{~kg} / \mathrm{l})$ 
$\boldsymbol{H}$ - Fee for financing the work of the Croatian Agency of Compulsory stocks of oil and oil products expressed in $\mathrm{Kn} / \mathrm{t}$

$\boldsymbol{B}$ - Fee for stimulating the production of biofuels

$\boldsymbol{P}$ - Premium for energy subjects in $\mathrm{Kn} / \mathrm{l}$

The Croatian oil model displayed above differs slightly from the Serbian, especially in terms of the traditional structure applied in the Western Balkans. Compared to other European countries, the price of oil derivatives in Croatia is not analytically divided into the basic price of oil, profit margin incurred due to refining, trade and distribution to final consumers, and VAT and excise duties (Cavrak et al., 2006). Compared to Serbia, where average oil prices are determined based on the global oil price and the dollar exchange rate, in Croatia oil prices are set on the basis of the prices of oil derivatives on the Mediterranean, not on the global prices of barrel of oil and the dollar exchange rate. Also, the structure of margins and excise duties, at a larger extent, affects the differences in the prices of oil products between EU member states.

According to the Slovenian Oil Model, oil prices are calculated on the following basis (Nemac and Saver, 1995, p.90)

$$
\Delta=\left[\left(C_{B R E N T} * K\right)+T_{R}+P_{R}+D_{R} *\left(P_{i} * \frac{C_{P A R} * p}{1000}\right)\right.
$$

Where:

$\Delta$ - Price change without tax

$(\mathrm{SIT} / \mathrm{l})$

CBRENT - Value according to Brent (Rotterdam)

(USD/bbl)

$\mathrm{K}$ - Relationship

$(\mathrm{USD} / \mathrm{bbl} \rightarrow \mathrm{USE} / \mathrm{t})$

TR -Transportationcosts

PR - Production costs

$\mathrm{Pt}$ - Exchange rates of business operations

CPAR - Parity

$\mathrm{P}$ - Specific weight

Compared to Serbia and Croatia which use market determined mechanism, Slovenia still uses a regulated fixed price mechanism. This model aims to free the country from day to day interventions on the expense of oil companies in Slovenia, which will be forced to risk their operating activities as a result of the variable oil price on the global market. For those oil derivatives that will remain under state control, 
the model will be based explicitly on the current parity of oil derivatives versus Brent crude oil. The defined parity in relation to Brent crude oil will be set based on the total tax exemption of derivatives (current purchase price of oil derivatives, including margin). The basis of the exempt oil products will be the trend of Brent crude oil prices and the exchange rates of the Euro and the US dollar. Prolongation of the automation of oil retail prices in Slovenia to some extent indicates on the reserved and secured policy which Slovenia has been implementing on the domestic oil market for years.

\section{STRUCTURE OF OIL RETAIL PRICES IN NORTH MACEDONIA AND THE EX YU REGION}

Despite the differences in oil retail price computation, each country is using similar parameters, extracted from the mathematical formulas above, in forming the final net price. The ratio of the final price is ultimately different in each country and varies according to the amount of economic gain imposed by the government. As displayed in Table 3, there are few main structures which companies in North Macedonia and the Ex Yu region are using to formulate its retail prices of $B M B 95$.

Table 3: Structure of oil retail prices of BMB 95 in North Macedonia and the Ex Yu region for $2019(€)$

\begin{tabular}{|c|c|c|c|c|c|c|c|}
\hline Country & $\begin{array}{c}\text { Basic } \\
\text { price } \\
(€ / \mathrm{l})\end{array}$ & $\begin{array}{l}\text { Fee for } \\
\text { oil } \\
\text { reserves }\end{array}$ & Excise & $\begin{array}{l}\text { VAT } \\
(\%)\end{array}$ & $\begin{array}{c}\text { Final } \\
\text { net } \\
\text { price } \\
(B M B \\
95)\end{array}$ & $\begin{array}{c}\text { State's } \\
\text { share } \\
(€)\end{array}$ & $\begin{array}{c}\text { State's } \\
\text { share } \\
\text { in } \\
\text { retail } \\
\text { price } \\
(\%)\end{array}$ \\
\hline $\begin{array}{c}\text { North } \\
\text { Macedonia }\end{array}$ & 0.58 & 0.01 & 0.36 & 0.17 & 1.10 & 0.54 & $49.09 \%$ \\
\hline Serbia & 0.54 & 0.02 & 0.51 & 0.21 & 1.28 & 0.73 & $59.34 \%$ \\
\hline Croatia & 0.54 & 0.03 & 0.52 & 0.26 & 1.35 & 0.81 & $60.11 \%$ \\
\hline $\begin{array}{c}\text { Bosnia and } \\
\text { Hercegovina }\end{array}$ & 0.53 & 0.02 & 0.38 & 0.15 & 1.08 & 0.55 & $50.92 \%$ \\
\hline Montenegro & 0.53 & 0.02 & 0.55 & 0.24 & 1.34 & 0.80 & $59.70 \%$ \\
\hline Slovenia & 0.54 & 0.03 & 0.51 & 0.22 & 1.30 & 0.76 & $58.46 \%$ \\
\hline
\end{tabular}

Source: Author's research

If we carefully review Table 3 we can easily perceive an evident difference among displayed countries. On the account of low excise duties and VAT, Bosnia and Hercegovina along with North Macedonia have the lowest price of $B M B 95$ in the region, $1.07 €$ and $1.10 €$ respectively. Next is Serbia, on the basis of the same account, with an average $B M B 95$ price of $1.28 €$. Croatia, Montenegro and 
Slovenia are countries with the highest excise and VAT values in the Ex Yu region, with an average net prices of $B M B 95$ of $1.32 €, 1.31 €$, and 1.30 respectively. The situation is relatively similar when it comes to comparing the state's share in net price and in overall retail price. Simply put, when the value of oil net price and states' share are divided, North Macedonia (49.09\%) and Bosnia and Hercegovina (50.92\%) have the lowest share in the overall retail price in the Ex Yu region. The states' share in retail price is relatively more emphasized in Slovenia (58.46\%), Serbia (59.34\%), and Montenegro (59.70\%), with Croatia $(60.11 \%)$ being the country with the absolutely highest state's share in oil retail price in the Ex Yu region.

The structure of the retail prices in North Macedonia and the region are subject to annual change and its values depends immanently from the countries energy politics. In case when the oil retail margin is the largest within the final oil price, the state is usually idle. Since oil taxes are collected in proportion to the price, the higher the price - the higher the inflow of money into the budget. Therefore, more expensive oil suits the state better. High oil prices tend to elevate the basis of VAT thus generating greater revenues for the government. On the other hand, distributors' income does not grow because they are obliged to pay higher amount. Hence they rather prefer a ratio of lower oil price and higher consumption.

The same rule applies for the excise duties. The increase of the amount of excise will not cause any additional financial implications for other legal entities, especially when the market is booming. When global oil prices follow a downward trend, this will cause governments to increase the excise value on oil products in order to consolidate its budget structure. Conversely, when oil prices are stable, the government can gradually return to its previous mechanism and reapply its old excise prices. Finally, when global oil prices are higher, countries tend to compensate for this by reducing excise duties in order to prevent sharp rise in the price of oil on the domestic market. If the proposed measure to increase excise duties does not have an adequate safeguard mechanism to reduce the impact of the prices of all other products, there might be an increase in inflation that will damage all branches in the economy. In a specific situation, even if the government increases the excise duties, oil companies might continue selling its products according to the original price listing. Thus oil company's expenses will remain at the approximately same level so oil prices were as if excise duties never actually changed at all.

In more developed countries, there is a certain threshold value which indicates that if the price of crude oil surpasses $50 \$$ dollars per barrel, the excise duties have one value. Otherwise, if the price is lower than $50 \$$ dollars, other excise value applies. In economic terms, this concept is known as floating excise, which means that the country does not want to generate money on the account of low oil prices. Instead, they want a fixed income from both VAT and excise duties. In other words, when oil prices increase, VAT revenues tend to grow dramatically, primarily on the account of decreasing excise duties. 
The value of oil retail prices of Diesel in North Macedonia and the Ex Yu region is relatively different from the price of $B M B 95$.

Table 3.1: Structure of oil retail prices of Diesel in North Macedonia and the Ex Yu region for $2019(€)$

\begin{tabular}{|c|c|c|c|c|c|c|c|}
\hline Country & $\begin{array}{c}\text { Basic } \\
\text { price } \\
(€ / \mathbf{l})\end{array}$ & $\begin{array}{c}\text { Fee for } \\
\text { oil } \\
\text { reserves }\end{array}$ & Excise & $\begin{array}{c}\text { VAT } \\
(\%)\end{array}$ & $\begin{array}{c}\text { Final } \\
\text { net price } \\
\text { (Diesel) }\end{array}$ & $\begin{array}{c}\text { State's } \\
\text { share } \\
(€)\end{array}$ & $\begin{array}{c}\text { State's } \\
\text { share in } \\
\text { retail } \\
\text { price } \\
(\%)\end{array}$ \\
\hline $\begin{array}{c}\text { North } \\
\text { Macedonia }\end{array}$ & 0.36 & 0.02 & 0.30 & 0.18 & 0.86 & 0.50 & $58.13 \%$ \\
\hline Serbia & 0.55 & 0.02 & 0.51 & 0.26 & 1.30 & 0.75 & $57.69 \%$ \\
\hline Croatia & 0.56 & 0.03 & 0.52 & 0.25 & 1.36 & 0.80 & $58.82 \%$ \\
\hline $\begin{array}{c}\text { Bosnia and } \\
\text { Hercegovina }\end{array}$ & 0.52 & 0.02 & 0.28 & 0.17 & 0.99 & 0.47 & $47.47 \%$ \\
\hline Montenegro & 0.54 & 0.02 & 0.55 & 0.25 & 1.36 & 0.82 & $60.29 \%$ \\
\hline Slovenia & 0.52 & 0.03 & 0.49 & 0.24 & 1.28 & 0.76 & $59.37 \%$ \\
\hline
\end{tabular}

Source: Author's research

Although Table 3.1, indicates a rather stable but yet progressive increase in value based on each parameter, these numbers are surprisingly equal or even higher compared to structure value of $B M B 95$. Again, North Macedonia and Bosnia and Hercegovina are the single countries in the Ex Yu region with the lowest diesel prices of $0.86 €$ and $0.99 €$ respectively. At the expense of the lowest VAT and excise duties, only these two countries have managed to maintain the price of diesel below $1 €$. Bosnia and Hercegovina did not only had the smallest monetary share of $0.47 €$ in the overall net price but also had the smallest percentage within the share in the overall retail price.

Compared to North Macedonia, Serbia and Slovenia had a significantly higher retail prices of diesel with a net price of $1.28 €$ and $1.30 €$ respectively. Oil companies in these countries sold its diesel fuel for approximately $0.44 €$ higher than oil companies in North Macedonia or $0.33 €$ higher than oil companies in Bosnia and Hercegovina. Moreover, Serbia is the single country in the Ex Yu region with the highest VAT of $26 \%$ on diesel prices, which in turn is $30 \%$ higher than the VAT of North Macedonia or $34 \%$ higher than the VAT in Bosnia and Hercegovina.

This price discrepancy is even larger $(0.5 €)$ when we align North Macedonia with Croatia and Montenegro, which are the countries with absolutely the highest price of diesel in the Ex Yu region. Additionally, Croatia and Montenegro have both surpassed the price value of $B M B 95$ with diesel prices 
of $1.36 €$ and $1.36 €$ respectively. High diesel prices in Croatia and Montenegro are consequently a result of the enormous excise price, which together encompasses nearly $38 \%$ of net price of diesel. In terms of the overall state inclusion, they both had a relatively equal share, with Montenegro being the country with the largest state's share in diesel retail price of $60.29 \%$.

When the retail price structure of both $B M B 95$ and Diesel is concisely reviewed, it is more than evident that the companies' financial share is significantly lower than the one of each country individually. For instance, if we abstract countries share from the oil retail price, the table hierarchy will change considerably. Therefore, companies have minor price maneuver options and they cannot simply lower its current prices which in turn might arouse revenues decline. The issue of excise duties on diesel prices - the fuel that drives the economy - is particularly sensitive, thus, depending on the activity, affects the operating costs. Higher diesel prices are a major problem for the entire economy, which might influence countries' competitiveness as well.

Oil companies are not prone to heavy state burdens, because as the price of oil increases, simultaneously, companies' turnover is decreasing. Large oscillations in oil prices as well as quotations of $B M B 95$ and Diesel are the main reasons why oil wholesalers are prone to increase the price, hence, increasing the prices at the fuel stations. The extent to which the upper level of VAT is been measured along with the impact of excise duties, depends primarily on the decision whether producers should pass this price increase on the consumers. Consumers' absorption power actually determines economic variations in the context of market demand. The higher the costs to consumers, the bigger the losses to retailers, due to a significant reduce in demand. The outcome is similar when the government reduces its subsidies for oil products. Consequently, producers tend to increase output prices in order to make up for the higher costs. Following the input-output relationship, a slight increase of oil prices tends to stimulate higher prices in other economic sectors.

In that context, the state has a legitimate right to determine different prices of excise duties on different types of oil, as long as these prices are in accordance with the minimum prescribed by the EU directives, which regulate the excise policy. Regarding oil retail prices, the structure of excise duties is harmonized throughout entire EU. The EU requires each European country to maintain a minimum excise duty of $0.36 €$ per liter for $B M B 95$ and $0.33 €$ per liter for diesel. Each country is obliged to adhere to these criteria in order to sustain a balance in terms of proper functioning of the domestic market in compliance with the principles of European legislation.

Chart 3.2: Excise prices of BMB 95 and Diesel for 2019 compared with EU criteria (€) 


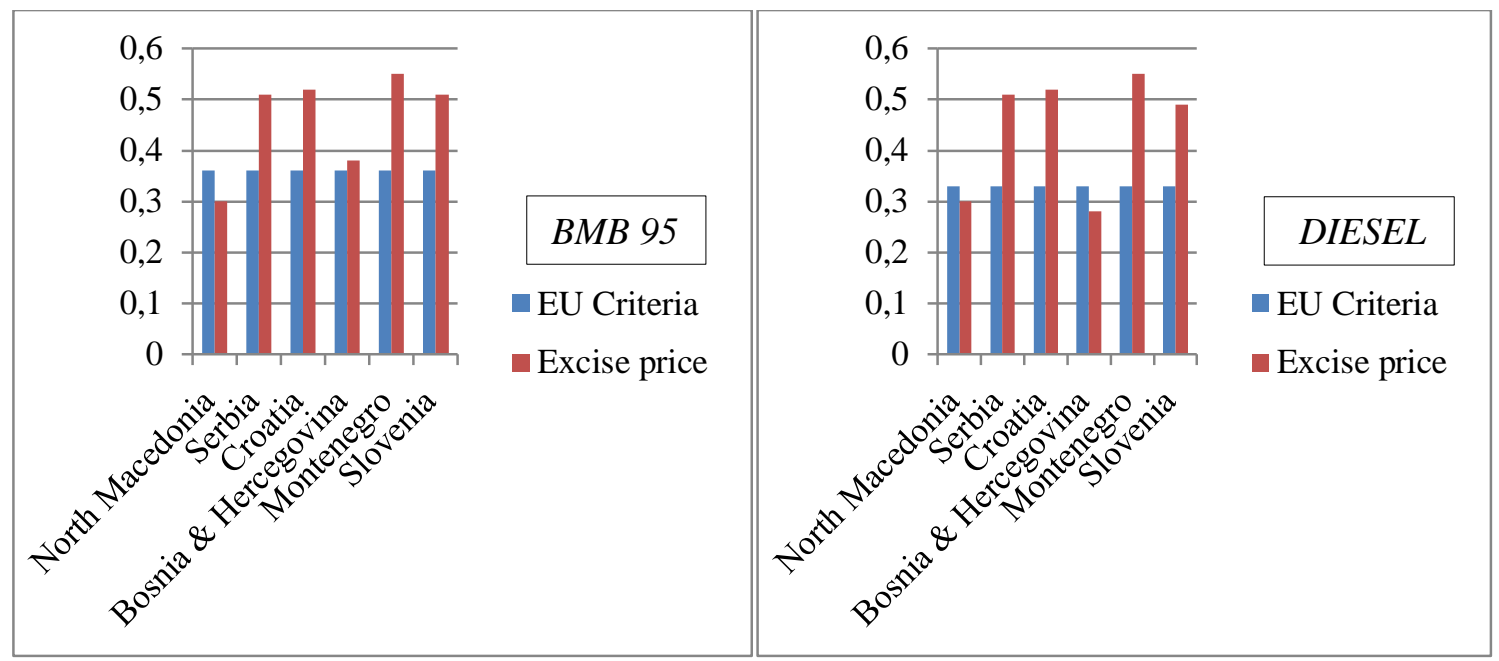

Source: European Commission (2019)

On the basis of the EU criteria, only North Macedonia has met the minimum criteria of $0.36 €$ for $B M B 95$ and $0.30 €$ for Diesel. As displayed in Chart 3.2, all remaining countries in the Ex Yu region have surpassed the minimum criteria, starting from Serbia with $0.15 €$ higher value for $B M B 95$ and $0.18 €$ for Diesel, followed by Croatia with higher value of $0.16 €$ for both BMB 95 and Diesel. Montenegro is the only country that had a value of excise duties of $0.25 €$ for $B M B 95$ and Diesel which is the highest value compared to all other countries in the Ex Yu region and almost half as high from the permissible criteria prescribed by EU. This indicates, with exception of North Macedonia, that each country in the Ex $\mathrm{Yu}$ region has broken the EU criteria by setting higher excise prices than allowed. Essentially, these numbers are not surprising at all, given the excessive involvement of countries' in the overall pricing process. Such a move, regardless of how cost effective is for the liquidity of each country's budget, is indeed detrimental for oil companies itself. Therefore it is of government paramount importance to create a pricing equilibrium where cost rationalization will be equally dispersed for the economic good of every oil company.

\section{OIL RETAIL PRICES BEFORE AND AFTER MARKET LIBERALIZATION IN NORTH MACEDONIA AND THE EX YU REGION}

Oil prices fluctuate widely throughout every economy. Its volatile character is quite unpredictable which makes them hard to follow. Thus observing oil prices from a fixed aspect might initiate a certain risk that the price ratio is atypical. The nature of the oil retail prices is driven by the legislative structure and the types of price mechanism applied in the economy. When the market is stable, oil retail prices tend to follow a steady pattern with minor variations in terms of price increase. This correlation is depicted in Chart 4 where the average oil retail prices for $B M B 95$ of all six companies before market liberalization is 
shown for the period from 2000 until 2010, denominated in Euros per liter (€/l). This specific time period is utilized in order to clarify that full market liberalization in certain countries in the Ex Yu region had not taken place before 2011. Referring to the price mechanism principles, each company was obliged to formulate its own oil retail prices in accordance with the methodology imposed by government entities. Overall, oil retail prices presented in Chart 4 were still under state regulation.

Chart 4: Average $B M B 95$ oil retail prices before market liberalization from 2000 to $2010(€ / 1)$

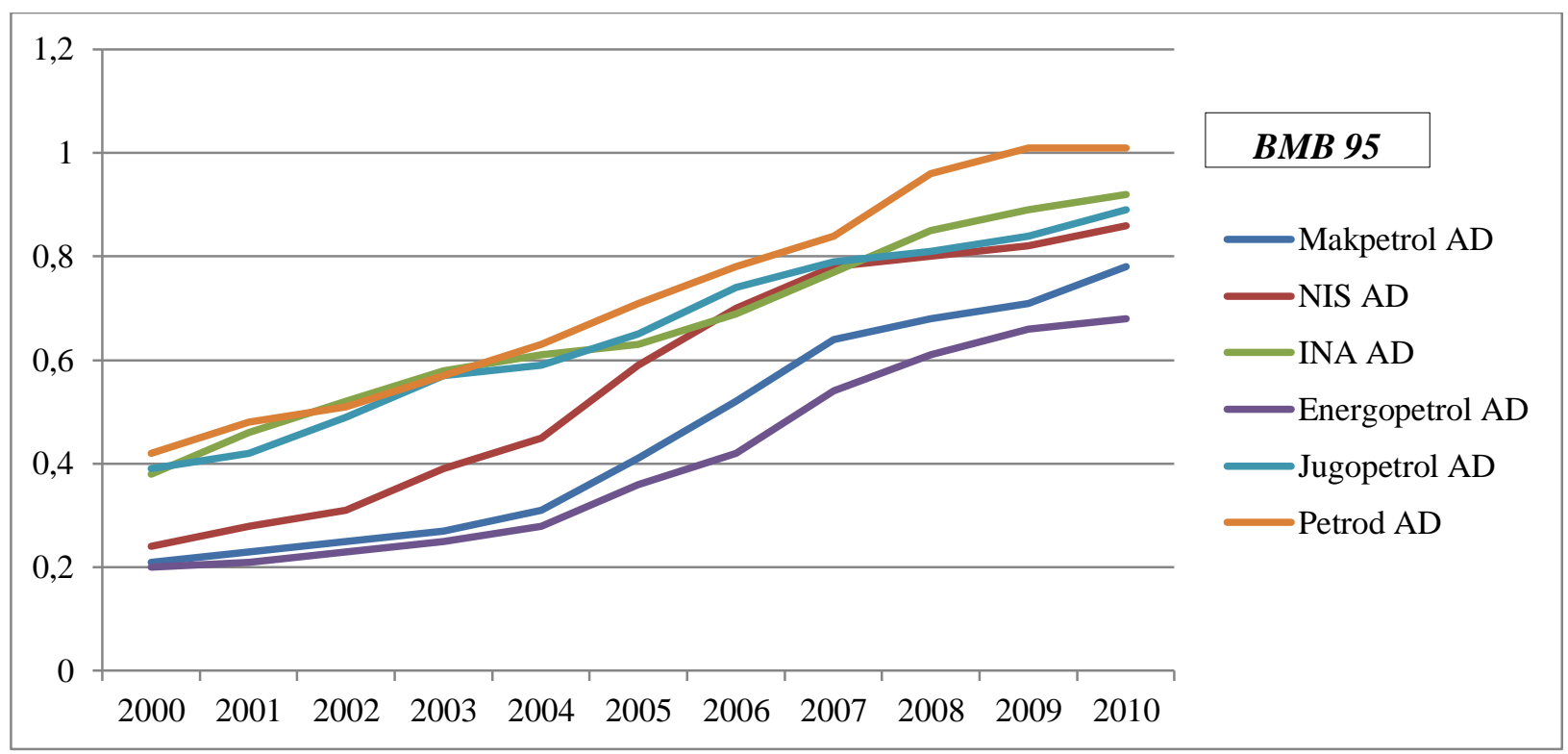

Source: Author's research

As shown in Chart 4, each company had a progressive growth of $B M B 95$ average prices for the period of 2000 to 2010. Despite the relatively growing trend of prices, neither company, except Petrol $A D$, had actually managed to exceed the price of $1 €$ for $B M B$ 95. Together, Petrol $A D$ and INA AD, which had follow an exponential price curve; have had the highest average oil retail prices in the Ex Yu region for $B M B$ 95. As the only $E U$ member countries today, they operate within more developed economies which entail different rules and regulations in accordance with $E U$ practices. In macroeconomic terms, this, however, has transformed its business standards enabling them to mitigate future demand variations through higher income. Moreover, Petrol $A D$ and INA $A D$ has advanced technologically due to its increased flow of foreign direct investments and enhancement of its diversification strategies. In addition, the retail oil prices of $B M B 95$ of $N I S A D$ had been growing progressively for the past decade, but with much lower value dynamics compared with oil retail prices of Petrol AD and INA AD. As Chart 4 indicates, the oil retail prices of $B M B 95$ of the other remaining companies were quite similar in value, with Makpetrol $A D$ and Energopetrol $A D$ being the oil companies with the lowest oil retail prices in the 
$\mathrm{Ex} \mathrm{Yu}$ region for the displayed period. The lower prices trend does not always mean bigger revenues. Conversely, this indicates that they have followed a similar price trajectory with small differences in price. This relation refers on the limited role of oil companies and its marginal inclusion in the pricing process. Before market liberalization, the price trajectory of Diesel oil for the period from 2000 to 2010 has been slightly different than the price of $B M B 95$ displayed above.

4.1. Average Diesel retail prices before market liberalization from 2000 to $2010(€ / 1)$

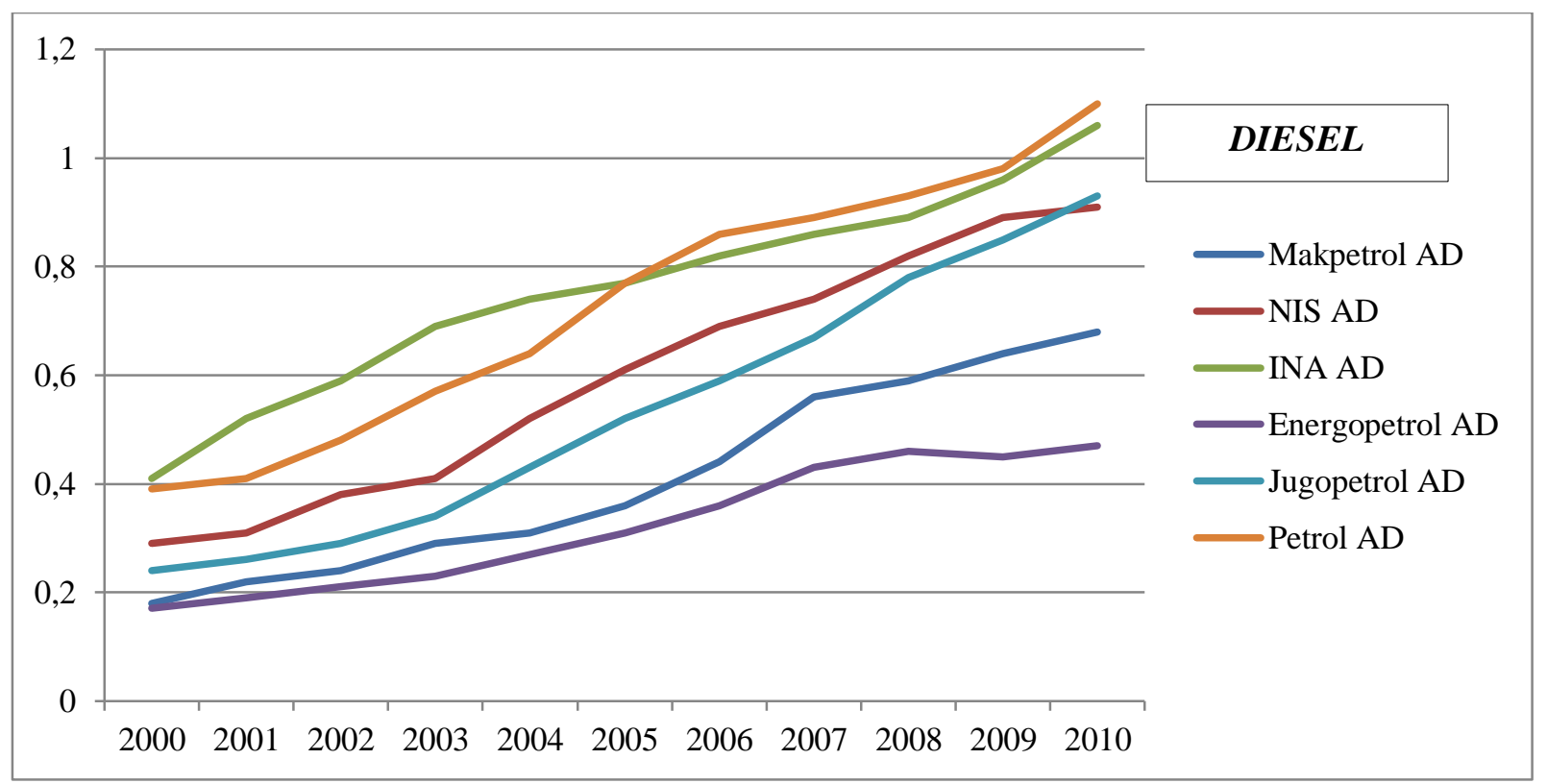

Source: Author's research

As presented in Chart 4.1, the upward trend of the average Diesel prices of each oil company is more than evident, especially if we examine its growth path separately. The fact is that Diesel prices, compared with the value of $B M B$ 95, had risen more slowly, but yet steadily for each country for the period from 2000 to 2010. There are no visible price variations, because the growth of Diesel prices has had a clear exponential character. Petrol $A D$ and INA $A D$ had registered the highest price of Diesel in 2010 of $1.06 €$ and 1.10 respectively. For the same period, Makpetrol AD and Energopetrol AD noted the lowest oil retail prices of Diesel in the Ex Yu region of $0.68 €$ and $0.47 €$ respectively. Diesel retail prices of NIS AD followed a similar trend, with a highest price of $0.89 €$ in 2010 , which is $16.8 \%$ lower than diesel prices of INA $A D$ and Petrol $A D$ and $25.27 \%$ higher than Diesel prices of Makpetrol AD and Energopetrol $A D$.

Table 4.2 indicates the price change of BMB 95 and Diesel from 2000 to 2010 before market liberalization. It is important to emphasize that within the presented time period, neither country had fully liberalized its market for oil derivatives. 
Table 4.2: Price increase of BMB 95 and Diesel from 2000 to 2010 before market liberalization

\begin{tabular}{|c|c|}
\hline $\begin{array}{c}\text { Company } \\
(\text { BMB 95 })\end{array}$ & $\begin{array}{c}\mathbf{2 0 0 0 - 2 0 1 0} \\
\text { Price Change } \\
(+/-)\end{array}$ \\
\hline Makpetrol AD & $\mathbf{+ 2 7 4 \%}$ \\
\hline NIS AD & $\mathbf{+ 2 5 8 \%}$ \\
\hline INA AD & $\mathbf{+ 1 4 2 . 1 1 \%}$ \\
\hline $\begin{array}{c}\text { Energopetrol } \\
\text { AD }\end{array}$ & $\mathbf{+ 2 4 0 \%}$ \\
\hline Jugopetrol AD & $\mathbf{+ 1 2 8 . 2 1 \%}$ \\
\hline Petrol AD & $\mathbf{+ 1 4 0 . 4 8 \%}$ \\
\hline
\end{tabular}

\begin{tabular}{|c|c|}
\hline $\begin{array}{c}\text { Company } \\
(\text { DIESEL })\end{array}$ & $\begin{array}{c}\mathbf{2 0 0 0 - 2 0 1 0} \\
\text { Price Change } \\
(+/-)\end{array}$ \\
\hline Makpetrol $A D$ & $\mathbf{+ 7 3 . 5 3 \%}$ \\
\hline NIS AD & $\mathbf{+ 2 1 3 . 1 1 \%}$ \\
\hline INA AD & $\mathbf{+ 1 5 8 . 5 4 \%}$ \\
\hline $\begin{array}{c}\text { Energopetrol } \\
\text { AD }\end{array}$ & $\mathbf{+ 1 7 6 . 4 7 \% \%}$ \\
\hline Jugopetrol $A D$ & $\mathbf{+ 2 8 7 . 5 7 \%}$ \\
\hline Petrol $A D$ & $\mathbf{+ 1 8 2 . 0 5 \%}$ \\
\hline
\end{tabular}

Source: Author's research

When the rise of the price of BMB 95 and Diesel is summed up for the past decade, it is more than evident that each company gained a significant increase in its retail prices. Based on its averaged retail price, the biggest growth of $B M B 95$ has been registered by Makpetrol $A D$ with a $274 \%$ overall increase in the period from 2000 to 2010, followed by NIS AD (258\%) and Energopetrol AD (240\%). For the same period, a relevant increase, but with relatively slower growth dynamics, was also registered by INA AD (142\%), Petrol AD (140\%) and finally Jugopetrol AD (140.48\%), which is the company with the lowest percentage increase of the retail price of $B M B 95$ in the last ten years.

The rise of Diesel prices within the period from 2000 to 2010 occurred as a consequence of the much faster annual growth of average retail prices. Energopetrol $A D$, the company with the lowest overall increase in $B M B 95$ has registered the highest overall growth of $287.57 \%$ of Diesel retail prices for the past ten years, followed by NIS AD (213.11\%), Petrol AD (182.05) and INA AD (158.54\%). Compared with its highest growth of $B M B$ retail prices in the region, Makpetrol $A D$ had registered the lowest overall increase in Diesel retail prices of $73.53 \%$ for the period from 2000 to 2010.

Generally, all companies have managed to maintain an exponential price curve due to its positive currency ratio, rising demand, and last but not least, the rising trend of the global oil prices, which reflected differently in each standard of the economy. Additionally, the price increase was noted as a result of the ever changing value of excise duties and VAT, which are the most variable parameters with dichotomous character, which can seriously increase or decrease the final retail price. Different management policies are an additional element which can, to a certain extent, contribute toward price restructuring policy by maintaining a secure position on the market. In the absence of fully liberalized 
market, price regulations are in fact the most effective tool for adjusting oil retail prices. The more practical those measures are, the greater the confidence of oil companies in responding to market changes.

Oil retail prices tend to differ when they are a subject of different market structure. Frequent changes in standards and operations, can seriously destabilize the oil market and obstruct the efforts of other oil companies which are completely liberalized. It is obvious that free market is the only choice where an oil retail price does not have to be regulated on the basis of bureaucracy and personal decisions. This will generate equal benefits for oil companies participating on the market and for consumers. However, the doctrinal approach of market liberalization, materialized as an escape of any kind of state interference in business relations, can indeed have devastating effect on market players as equal as monopoly.

In absolute terms, liberalization has a multiple effect on each country's economy. The effectiveness of this process depends solely from the type of managerial and legal practices applied in different market scenario. Whether liberalization will initiate an increase or a decrease of oil retail prices is a question which can be addressed from both theoretical and practical aspect. Chart 4.3 shows the average $B M B 95$ retail prices after market liberalization from the period of 2011 to 2019.

Chart 4.3: Average $B M B 95$ retail prices after market liberalization from 2011 to $2019(€ / 1)$

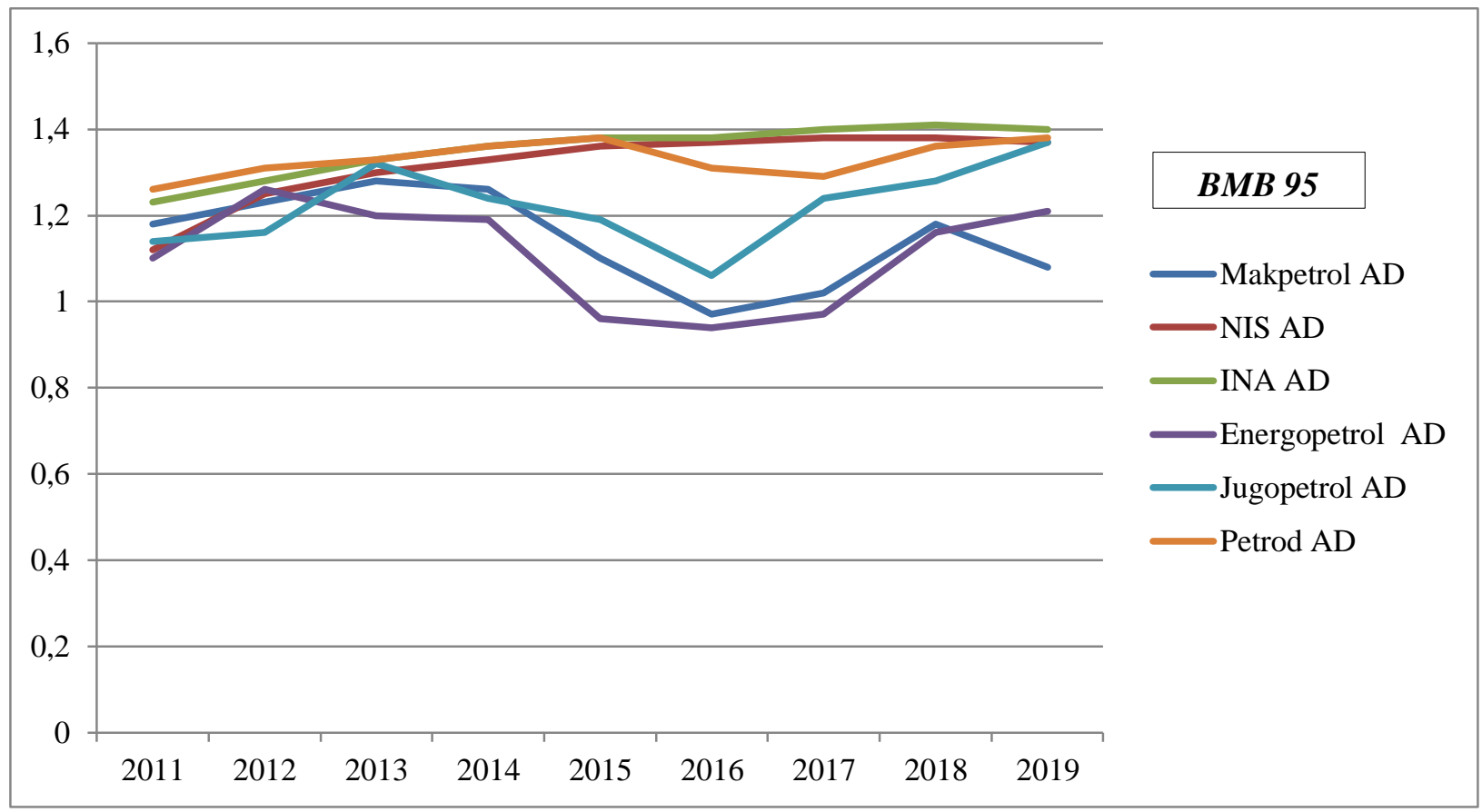

Source: Author's research

As mentioned previously, only two countries/companies have managed to fully liberalize its market for oil derivatives - Serbia (NIS AD) in 2011 and Croatia (INA AD) in 2014. All other countries 
are still operating within a regulated market, with price celling or fixed price mechanism applied. Thus oil retail prices of each company on the market are identical in value, with no price variations whatsoever. Referring to Chart 4.3., Makpetrol $A D$ and Energopetrol $A D$ have had the lowest average price of $B M B$ 95 in the region, with overall price decrease from 2014 to 2017 of $23.02 \%$ and $21.01 \%$ respectively. Similar trend was depicted in the case of Jugopetrol AD, with an overall decrease in oil prices from 2013 to 2016 of $19.17 \%$. However, the downward price curve of Jugopetrol AD has managed to revive in the middle of 2016, where an uprising trend of retail prices of $28.82 \%$ was registered from 2016 to 2019. Petrol $A D$ has also generated an overall growth of oil retail prices of $9.52 \%$ from the period of 2011 to 2015, with small price decrease of $1.53 \%$ from 2016 to 2017.

As of 2011, Serbia has fully liberalized its oil market by enabling the long-awaited method of free formation of oil derivative prices. In essence, the liberalization was aimed to stimulate more competition on the market and thus lower the prices of oil derivatives. However, in the case of Serbia, the liberalization process itself had a contra productive effect on the value of retail prices. This price variation is illustrated in Chart 4.3 where is more than evident that oil retail prices of NIS AD generated increase from 2011 to 2019. In the same fashion as Serbia, full market liberalization was also implemented in Croatia in 2014, which instead of a decline, caused prices to rise sharply.

Table 4.4: Price increase/decrease of BMB 95 after market liberalization from 2011 to $2019(€ / 1)$

\begin{tabular}{|c|c|c|c|}
\hline $\begin{array}{l}\text { Company } \\
\text { (BMB 95) }\end{array}$ & $\begin{array}{c}\text { Price change } 2011 \\
-2019 \\
(+/-)\end{array}$ & $\begin{array}{l}\text { NIS AD Price } \\
\text { change after } \\
\text { market } \\
\text { liberalization }(+/- \\
\text { ) }\end{array}$ & $\begin{array}{c}\text { INA } \boldsymbol{A D} \text { Price } \\
\text { change after } \\
\text { market } \\
\text { liberalization } \\
(+/-)\end{array}$ \\
\hline & & $2011-2019$ & $2014-2019$ \\
\hline Makpetrol AD & $-8.47 \%$ & $+22.32 \%$ & $+3.68 \%$ \\
\hline NIS AD & $+22.32 \%$ & & \\
\hline INA AD & $+11.11 \%$ & & \\
\hline Energopetrol $A D$ & $+10 \%$ & & \\
\hline Jugopetrol AD & $+20.18 \%$ & & \\
\hline Petrol AD & $+9.52 \%$ & & \\
\hline
\end{tabular}

Source: Author's research

The full market liberalization effect is displayed in Table 4.4 where the main focus is on the oil retail prices (BMB 95) of INA AD and NIS AD. Since the market was liberalized in 2011, it is more than noticeable that it has significantly increased oil retail prices of $B M B 95$ in Serbia for $22.32 \%$ for period from 2011 to 2019. Since liberalization of oil derivatives in Croatia has started in 2014, a relative overall increase of $3.68 \%$ of oil retail prices was also noticed. When these numbers are interpreted in the context 
of market liberalization, it can easily be confirmed that liberalization, instead of reducing, has actually stimulated higher oil retail for consumers in Serbia and Croatia. The most dramatic consequence of liberalization is practically visible in oil companies in Serbia and Croatia, which used the free market pricing system to raise margins and sell more expensive oil.

Chart 4.5: Average Diesel retail prices after market liberalization from 2011 to 2019 (€/l)

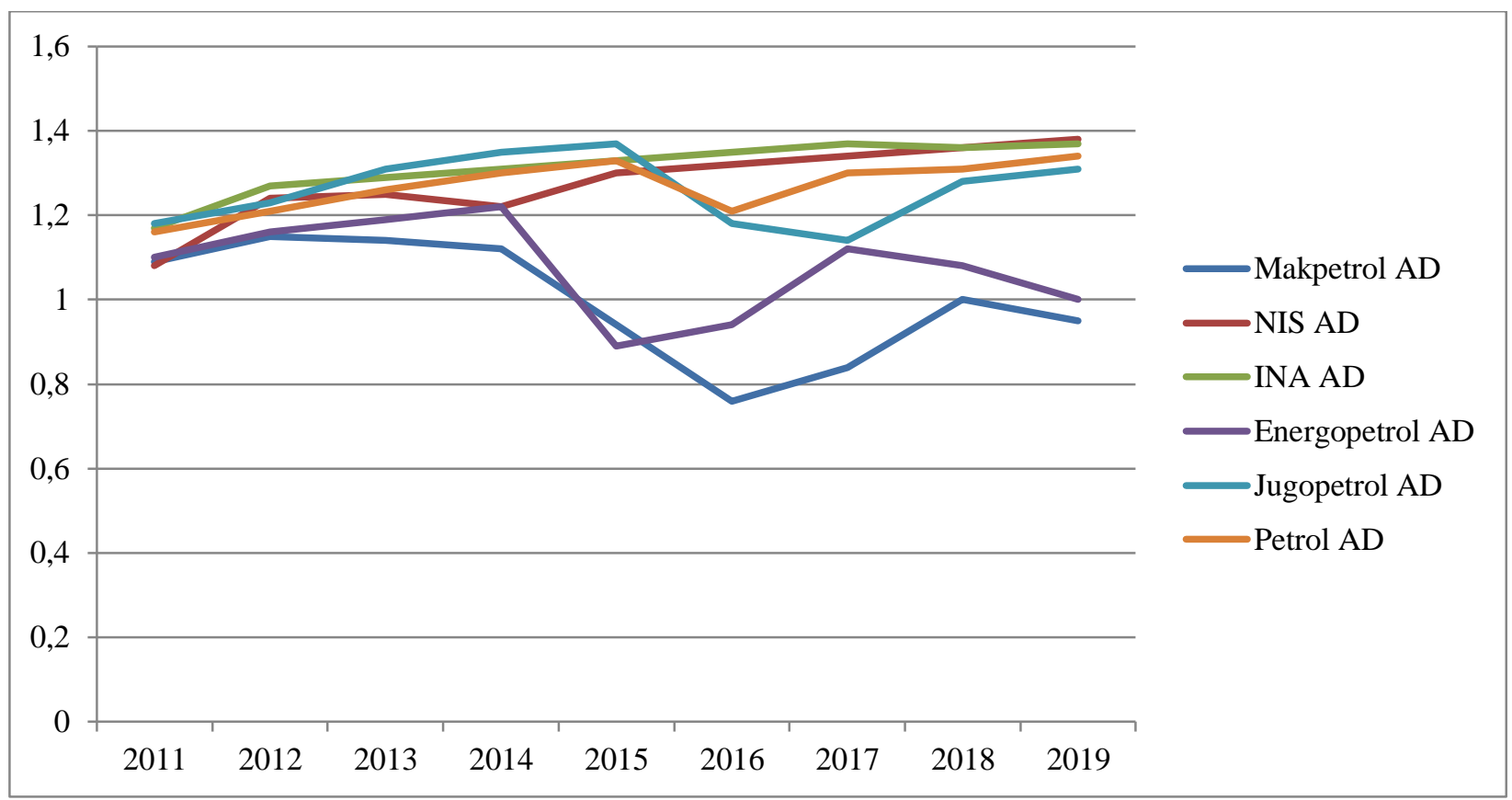

Source: Author's research

As shown in Chart 4.5 Diesel prices have followed a relatively cyclical trend, with simultaneously dramatic declines and express increase of retail prices. Makpetrol $A D$ has registered an overall decline in Diesel retail prices of 34.48\% from the period from 2012 to 2016 and have had the lowest Diesel price in the region, along with Energopetrol AD. Significant increase in Diesel retail prices was also achieved by Petrol AD, with an overall growth of $14.66 \%$ from 2011 to 2015 . This uprising trend, however, has started to decline from 2015 to 2016, which decreased Diesel retail prices of Petrol $A D$ for $9.02 \%$. Similar growth pattern of Diesel prices was also registered by Jugopetrol AD, which for the period from 2011 to 2015 has managed to maximize its Diesel retail prices and gain an overall increase of $16.14 \%$. Only two companies have gained continuous growth without any serious price fluctuations of Diesel retail prices - NIS $A D$ and INA $A D$. After the completion of the market liberalization process, they both managed to maintain a remarkably high value of Diesel prices - the highest one in the region. 
Table 4.6: Price increase/decrease of Diesel after market liberalization from 2011 to $2019(€ / 1)$

\begin{tabular}{|c|c|c|c|}
\hline $\begin{array}{l}\text { Company } \\
(\text { DIESEL })\end{array}$ & $\begin{array}{c}\text { Price change } \\
2011-2019 \\
(+/-)\end{array}$ & $\begin{array}{l}\text { NIS } A D \text { Price } \\
\text { change after } \\
\text { market } \\
\text { liberalization } \\
(+/-)\end{array}$ & $\begin{array}{c}\text { INA } \boldsymbol{A D} \text { Price } \\
\text { change after } \\
\text { market } \\
\text { liberalization }(+/- \\
)\end{array}$ \\
\hline & & $2011-2019$ & $2014-2019$ \\
\hline Makpetrol AD & $-12.84 \%$ & $+27.78 \%$ & $+4.58 \%$ \\
\hline NIS AD & $+27.78 \%$ & & \\
\hline$I N A A D$ & $+17.09 \%$ & & \\
\hline Energopetrol $A D$ & $-9.09 \%$ & & \\
\hline Jugopetrol AD & $+11.02 \%$ & & \\
\hline Petrol AD & $+15.52 \%$ & & \\
\hline
\end{tabular}

Source: Author's research

Table 4.6 shows the sublimated effect that liberalization had on Diesel prices for the period from 2011 to 2019 with particular focus on INA AD and NIS AD. Along with BMB 95 price growth, the retail prices of Diesel, after the implementation of full market liberalization, showed an express increase in value. The price increase was particularly evident at NIS AD which achieved a significant rise of $27.78 \%$ of Diesel prices after market liberalization, which are actually the highest prices of Diesel in the Ex Yu region. After market liberalization, a relevant rise of $4.58 \%$ of Diesel prices was also registered by INA $A D$.

If we compare these numbers with the value of $B M B 95$ after market liberalization, it is more than evident that the prices of Diesel grew faster than the prices of BMB 95. Diesel prices of NIS AD were $5.46 \%$ higher than prices of $B M B 95$ whereas Diesel prices of INA $A D$ were $0.9 \%$ higher than the prices of $B M B$ 95, after market liberalization. The rise of Diesel prices in the region was explicitly high due to the fact that Diesel has become extremely expensive all over the world. Refineries have modernized and reoriented themselves toward lighter fuels, on which they are trying to create added value. This means that there is more $B M B$ and less Diesel fuels on the market and less Diesel with the same number of consumers' usually means higher prices. The continuous rise of Diesel prices is actually a result of the new regulations of productions, which entail different set of rules toward producing cleaner Diesel fuels, and an additional financial burden on refineries, by increasing their costs. 


\section{DISCUSSION}

Theoretical perceptions regarding market liberalization are prone to have different interpretation once applied in practice. The way that liberalization has affected oil retail prices is relatively different, especially in those countries where this process has ended completely. This is the case with NIS AD and INA $A D$ which both managed to set the highest prices of oil derivatives on its market. They have managed to capitalize on its leadership position on the market by utilizing its broad retail network as a competitive advantage. Liberalization, instead of advancing the competitive character of the market, has additionally strengthened the monopoly position of oil companies. Current positioning has indeed a negative effect on other oil companies on the market, by narrowing its opportunities to differentiate and compete on prices and quality. The negative effect of liberalization is mainly reflected on consumers, which expect a more differentiated offer and lower prices. In that context, liberalization had only removed government obstacles and enable market determined prices which have not generated yet the desired outcome. The inverse effect of liberalization on oil prices in Serbia and Croatia is mainly a consequence of the slow adaptation of the new instruments that are set to produce more quality fuel with relatively lower prices.

When the market is not ready, there are certain conditions as to whether liberalization should be carried out in the first place. The structure of the market and the number of oil companies are just one the few indicators whether the market has the right potential to be fully liberalized. That is the situation with North Macedonia and other countries in the region, where the process of liberalization is continuously delayed. When a single company has a dominant market share and the market is misbalanced in terms of competitive ratio, there is an opportunity for the leading company to abuse its position in the context of determining higher prices. Liberalization does not always correspond with the content of each market and the more homogenous the product is the lower the opportunities for market differentiation. Until the market does not change its operating policy, any attempt of the government to fully liberalize the oil market will be a complete failure. Indeed, when there are no conditions for full market liberalization, it is more effective for the government to regulate oil prices in order to avoid unwanted price increase. Therefore it is of utmost importance to stimulate new market entries which in turn will generate bigger competition and enable market liberalization to evolve naturally.

\section{CONCLUSION}

Liberalization, perceived from the market economy perspective, should essentially stimulate competition and contribute toward significant reduction in oil retail prices, not vice versa. The number of market players is crucial when it comes to oil price liberalization. Thus as the rivalry increases, a gradual decrease of oil retail prices is expected. A market responsible state, if such a thing exists within the oil 
industry, provides everyone equal opportunities in the long run, which is actually the essence of any liberalization. The more equal these chances are, the less it is necessary for the state to interfere in the business.

Market liberalization is always an act of the state, and the greatest quality of market liberalization policy is in essence continuity. That is a constant effort to preserve the positive effects of liberalization and prevent monopolization. When the effect of liberalization becomes a part of the company's business culture and integral component of its social values, then it can be said that this process has succeeded, but not yet completed. Therein lies the answer to the question whether market liberalization is necessary in a first place. It is indeed necessary, but it does not end in one move. Liberalization is a time consuming process and as such imposes a series of legal instruments necessary for the implementation to be successful. The biggest issue is the lack of adequate regulations and mechanism that would force participants in the oil market to behave in a competitive manner. Oil companies should struggle to attract and gain consumers based on better service, quality and price, not on higher prices of oil derivatives. Nowhere in the world is there such a liberalized market which allows oil companies to gain extra profit selling oil derivatives, which is ultimately paid off by consumers. If oil margins start to grow uncontrollably, the government will be force to intervene and mitigate this impact by applying legal measures extracted from EU and other developed countries.

A liberalized market requires fair play and mutual respect of the principles of open competition. In the free price formation system with an open market competition, where one freely imports and exports its oil derivatives, rivalry among companies guarantees consumers the lowest possible price. Hence market liberalization does not imply arbitrary behavior of market participants but rather respect for those regulations of the government which controls that market.

\section{REFERENCES}

Acheampong, T. \& Ackah, I. (2015). Petroleum Product Pricing, Deregulation and Subsidies in Ghana: Perspectives on Energy Security, MPRA Paper, 1-12

Association of Oil Companies of Serbia (2011). Analize trzista derivate nafte Republike Srbije, Nacionalni Naftni Komitet Srbije - WPC, 1-15

Bacon, R. \& Kojima, M. (2010). "Rockets and Feathers: Asymmetric Petroleum Product Pricing in Developing Countries", World Bank - Oil, Gas, Mining Policy Division Working Paper. 1-43

Bajo, A. \& Klemencic, I. (2012). “Cijena nafte i naftnih derivata”, Porezni vijesnik, 21 (7), 117-132.

Baumol, W.J., Panzar, J.C., and Willig, R.D. (1982). Contestable Markets and the Theory of Industry Structure. New York: Harcourt, Brace, Jovanovich.

Benedict, C., Jung, H.S., and Gupta, S. (2003). "Real and Distributive Effects of Petroleum Prices Liberalization: The Case of Indonesia. IMF Working Paper, 1-19. 
Carollo, S. (2011). Understanding Oil Prices: A Guide to What Drives the Price of Oil in Today's Markets. The Wiley Finance Series.

Capece, G., Cricelli, L., Di Pillo, F., Levialdi, N. (2007). "Impact of Liberalization on Italian Retail Gas Prices, Conference Paper: The $16^{\text {th }}$ IASTED International Conference on Applied Simulation and Modeling, 403-408

Cavrak, V., Gelo, T., and Pripuzic, D. (2006). "Politika Cijena u Energetskom Sektoru I Utjecaj Cijena Energenata na Gospodarski Razvoj Republike Hrvatske”, Zbornik Ekonomskog Fakulteta u Zagrebu, Vol. 4, 45-67

Danwitz, T. (2006). "Regulation and liberalization of the European Electricity Market - A German View, Energy Law Journal, Vol. 27, 423-449

Debab, N. and Radhi, S.J. (2011). "Effects of Trade Liberalization on Domestic Consumers Prices: A case study of Gulf Cooperation Council, European Journal of Economics, Finance, and Administrative Science, Issue 37, 148-159

ERC. (2019). Energy Regulatory Commission of North Macedonia. ERC: https://www.erc.org.mk/pages.aspx?id=18

European Commission (2018). Excise duties Tables. European Commission: https://ec.europa.eu/taxation_customs/sites/taxation/files/resources/documents/taxation/excise_duties/energy_products/r ates/excise duties-part ii energy products en.pdf

Fasoula, E. \& Schweikert, K. (2018). "Price regulations and price adjustment dynamics: Evidence from the Austrian retail fuel market", Hohenheim Discussion Papers in Business, Economics, and Social Sciences, 1-21

Husain, A.M., Arezki, R., Breuer, P., Haksar, V., Helbling, T., Medas, P., Sommer, M. (2015). "Global Implications of Lower Oil Prices", Working Paper, 1-41

Garcia, J.P. (2010). "Dynamic pricing in the Spanish gasoline market: A tacit collusion equilibrium", Energy Policy, 38 (4), 1931-1937

Goldthau, A. \& Witte, J.M. (2008). Global Energy Governance: The New Rules of the Game. Brooking Institution Press.

Kojima, M. (2013). "Petroleum product pricing and Complementary policies: Experience of 65 Developing countries since 2009" Policy Research Working Paper 6396, The World Bank Sustainable Energy Department Oil, Gas, and Mining Unit.

Mitchell, J., Marcel, V., and Mitchell, B. (2012). What Next for Oil and Gas Industry? Chatam House. The Royal Institute of International Affairs, 1-108

Musselli, I. \& Zarrilli, S. (2005). “Oil and Gas Services: Market Liberalization and the Ongoing GATS Negotiations”, Journal of International Economic Law, 8 (2), 551-581

Nemac, F. \& Saver, A. (1995), "Price Models for oil derivatives in Slovenia” Agency for Energy Restructuring Ljubljana, Slovenia, 87-95

Joubert, P., Celestin, N., Celestin, T.S., and Ledoux, S. (2018). "The Impact of Liberalization on Petroleum Product Prices on the Economy of Cameroon", Working Paper 346, African Economic Research Consortium, Research Department, 1-66

Price, W.C. (2007). "The effect of liberalizing UK retail energy markets on consumers", Oxford Review of Economic Policy, 21 (5), 128-144

Pollitt, M.G. (2012). "The role of policy in energy transition era: lessons from the energy liberalization era, Cambridge Working Paper on Economics 1208, 1-29

Porter, M.E. (1985). The Competitive advantage: Creating and Sustaining Superior Performance. New York: Free Press.

Pintado, A.B. \& Cavero, S. (2007). "The Spanish retail petroleum market: New patterns of competition since the liberalization of the industry", Energy Policy, 36 (2), 612-626

Szulecki, K. (2016). "European energy governance and decarbonization policy: learning from the 2020 strategy", Climate Policy, $16(5), 543-547$ 
Udovicki, K. \& Djokovic, V. (2005). "Kvalitet i cenovna struktura naftnih derivata: Uvodne I metodoloske napomene", Quarterly monitor of economic trends in Serbia, No.3 Oct-Dec, 1-9

Wieringa, J.E. \& Verhoef, P.C. (2007). "Understanding Customer Switching Behavior in a Liberalized Service Market: An Exploratory Study, Journal of Service Research, 10 (2), 174-186 